\title{
Decreased In Vivo Glucose Uptake but Normal Expression of GLUT1 and GLUT4 in Skeletal Muscle of Diabetic Rats
}

\author{
Barbara B. Kahn, Luciano Rossetti, * Harvey F. Lodish, $\$$ and Maureen J. Charron* \\ The Charles A. Dana Research Institute and Harvard Thorndike Laboratory of Beth Israel Hospital, Department of Medicine, Harvard \\ Medical School, Boston, Massachusetts 02215; *Department of Medicine, Diabetes Division, University of Texas Health Science Center, \\ San Antonio, Texas 78284; ${ }^{\ddagger}$ The Whitehead Institute for Biomedical Research, Cambridge, Massachusetts 02142; \\ and ${ }^{\$}$ Department of Biology, Massachusetts Institute of Technology, Cambridge, Massachusetts 02139
}

\begin{abstract}
This study was designed to determine whether altered glucose transporter expression is essential for the in vivo insulin-resistant glucose uptake characteristic of streptozocin-induced diabetes. Immunofluorescence in rat skeletal muscle colocalizes GLUT4 with dystrophin, both intrinsic to muscle fibers. In contrast, GLUT1 is extrinsic to muscle fibers, probably in perineurial sheath. Immunoblotting shows that levels of GLUT1 and GLUT4 protein per DNA in hindlimb muscle are unaltered from control levels at $7 \mathrm{~d}$ of diabetes but decrease to $\sim 20 \%$ of control at $14 \mathrm{~d}$ of diabetes. This decrease is prevented by insulin treatment. In adipose cells of 7 d diabetic rats, GLUT4 levels are depressed. Thus, GLUT4 undergoes tissuespecific regulation in response to diabetes. GLUT4 and GLUT1 mRNA levels in muscle are decreased $62-70 \%$ at both 7 and $14 \mathrm{~d}$ of diabetes and are restored by insulin treatment. At $7 \mathrm{~d}$ of diabetes, when GLUT4 protein levels in muscle are unaltered, in vivo insulin-stimulated glucose uptake measured by euglycemic clamp is $54 \%$ of control. This reflects impairment in both glycogen synthesis and glycolysis and the substrate common to these two pathways, glucose-6-phosphate, is decreased $\sim 30 \%$ in muscle of diabetic rats. These findings suggest a defect early in the pathway of glucose utilization, probably at the step of glucose transport. Because GLUT1 and GLUT4 levels are unaltered at $7 \mathrm{~d}$ of diabetes, reduced glucose uptake in muscle probably reflects impaired glucose transporter translocation or intrinsic activity. Later, at $14 \mathrm{~d}$ of diabetes, GLUT1 and GLUT4 protein levels are reduced, suggesting that sequential defects may contribute to the insulin-resistant glucose transport characteristic of diabetes. (J. Clin. Invest. 1991. 87:21972206.) Key words: glucose transporter • glucose disposal • hexose transport • insulin action • streptozotocin diabetes
\end{abstract}

\section{Introduction}

Recent molecular cloning studies have revealed that a family of glucose transporter proteins is expressed in mammalian tissues

Address correspondence to Barbara B. Kahn, M.D., Diabetes Unit, Beth Israel Hospital, 330 Brookline Ave., Boston, MA 02215.

Dr. Charron's present address is Department of Biochemistry, Albert Einstein College of Medicine, 1300 Morris Ave., Bronx, NY 10461.

Received for publication 28 August 1990 and in revised form 31 December 1990.

J. Clin. Invest.

(c) The American Society for Clinical Investigation, Inc. $0021-9738 / 91 / 06 / 2197 / 10 \quad \$ 2.00$

Volume 87, June 1991, 2197-2206
(1-11). At least two of these transporters, GLUT1 and GLUT4, coexist in tissues in which glucose transport is markedly stimulated by insulin, i.e., muscle and adipose cells. Although GLUT1 is also expressed in numerous tissues in which glucose transport is not highly regulated by insulin, GLUT4 is confined primarily to these markedly insulin responsive tissues (1-11). Several lines of evidence suggest that GLUT4 is the major glucose transporter in muscle and adipose cells $(6,12-14)$.

To understand the cellular and molecular mechanisms responsible for in vivo insulin resistance in states such as diabetes and fasting, the regulation of glucose transporter expression was recently studied in adipose cells (15-19). Initially, adipose cells were thought to be a model for muscle because in both tissues the acute increase in glucose transport in response to insulin appears to result, at least in part, from the translocation of glucose transporters from an intracellular pool to the plasma membrane (20). The expression of GLUT4 in adipose cells was reduced at both the mRNA and protein levels with diabetes and restored with insulin treatment (15-19); GLUT1 expression was much less affected. These observations led to the hypothesis that the level of expression of GLUT4 is a major determinant of insulin-stimulated glucose transport in insulin-responsive tissues.

However, we recently showed that GLUT1 and GLUT4 expression are subject to tissue-specific regulation (21). Importantly, mRNA and protein levels for both transporters are increased in muscle of fasted rats whereas expression of both transporters is decreased in adipose cells from the same rats. The increase in GLUT4 protein levels in muscle of fasted rats (21) is in agreement with earlier studies that showed increased or normal insulin-stimulated glucose uptake in isolated soleus muscle (22) and perfused hindlimb $(23,24)$ from fasted rats. Because fasting is associated with resistance to the stimulatory action of insulin on glucose uptake in vivo (21), and muscle is responsible for $>80 \%$ of insulin-mediated glucose uptake in vivo $(25,26)$, these observations raise the question as to whether GLUT4 expression is a major determinant of in vivo glucose uptake in muscle.

The ability of insulin to stimulate glucose uptake in skeletal muscle is impaired at the whole body and cellular levels in human diabetes mellitus (27-30) and at the whole body level (31) in animal models of diabetes while studies in incubated or perfused skeletal muscle of diabetic rodents variably show increased insulin sensitivity (22) with normal maximal response $(22,24,32,33)$ or decreased maximal insulin stimulated glucose uptake (34-36). Decreased glucose uptake may be the consequence of impaired glucose transport activity and/or defective intracellular metabolism of the transported glucose. Once glucose is transported into the cell, it is phosphorylated to 
glucose-6-phosphate (G-6-P) ${ }^{1}$ and enters one of two major pathways, glycogen synthesis or glycolysis. In diabetic states, defects have been demonstrated at the level of glucose transport $(30,37)$, glycogen synthase $(38)$, and pyruvate dehydrogenase (39). Decreased flux through the glycogenic and/or the glycolytic pathway, in the presence of normal glucose transport activity, may result in an increase in G-6-P concentration which in turn inhibits glucose phosphorylation and transport (40).

The overall aim of the present study was to examine the significance of glucose transporter expression for glucose uptake in vivo. That is, can altered expression of either GLUT1 or GLUT4 account for altered in vivo glucose uptake in diabetic rats? To answer this question, we first determined the localization of these two transporters in skeletal muscle because previous studies suggested that GLUT1 was primarily in the perineurial sheath (41) and GLUT4 in endothelial cells (42). Immunofluorescence studies localize GLUT1 exclusively to structures extrinsic to muscle fibers in control, diabetic and insulin-treated diabetic rats. In contrast, GLUT4 is present within muscle fibers. This is in agreement with a recent study using immuno-gold labeling which also demonstrates that GLUT4 is associated with muscle fibers (43).

Our results show that after $7 \mathrm{~d}$ of diabetes, the stimulatory effect of insulin on skeletal muscle glucose uptake in vivo is severely impaired in spite of unchanged levels of GLUT1 or GLUT4 polypeptides. This impaired glucose uptake is associated with reduced muscle glycogen synthesis and glycolysis and decreased levels of intracellular G-6-P, implying a proximal defect in the pathway of glucose utilization, probably at the level of transport. After $14 \mathrm{~d}$ of diabetes, the expression of GLUT1 and GLUT4 diminishes; this decrease is prevented by insulin therapy after $7 \mathrm{~d}$ of diabetes. These findings suggest that sequential defects contribute to the insulin resistant glucose transport in skeletal muscle of diabetic rats. Importantly, marked in vivo insulin resistance can be present without alteration in glucose transporter polypeptide levels in skeletal muscle. Thus, functional impairment of glucose transporters due to impaired translocation and/or diminished activity is likely to be a major determinant of insulin-resistant glucose uptake associated with diabetes.

\section{Methods}

\section{Animals and experimental design}

Male Sprague-Dawley rats (CD strain, Charles River Breeding Laboratories, Wilmington, MS) were received at body weights ranging from 150 to $160 \mathrm{~g}$ and maintained with ad libitium feeding of standard chow for several days before initiation of the experimental period. Rats were treated with injection of $80-85 \mathrm{mg} / \mathrm{kg}$ i.p. anhydrous streptozocin and citric acid (Zanosar; Upjohn Co., Kalamazoo, MI) reconstituted with $0.9 \%$ saline. Rats were maintained diabetic for 7-14 d. After 7-11 d of hyperglycemia some rats were treated with subcutaneous insulin infusion (4 U/d) via osmotic minipumps as previously described (44). Control rats received no treatment, as sham injections had no effect on blood glucose concentrations or in vivo glucose uptake $(31,44)$. Glucose was measured in whole blood using Chemstrips bG (Bio-Dynamics, Indianapolis, IN) read in an Accuchek II bG reflectance meter (Bio-Dynamics). Values $>33.3 \mathrm{mM}$ were estimated by visual comparison with the color chart supplied with the strips. For RNA, protein, and

1. Abbreviation used in this paper: G-6-P, glucose-6-phosphate. immunofluorescence studies, animals were killed by $\mathrm{CO}_{2}$ inhalation followed by decapitation. Gastrocnemius and soleus muscles were rapidly removed, dissected free of connective tissue, and frozen in liquid nitrogen. No fixative was used for immunofluorescence studies as antigenicity was greatly reduced by fixation.

\section{Localization of GLUT1 and GLUT4 using immunofluorescence}

Preparation and characterization of GLUT1 and GLUT4 anti-peptide antibodies. Peptides containing the amino terminal 13 amino acids (CMPSGFQCIGSEDG) and the carboxy terminal 16 amino acids (CVKPSTELEYLGPDEND) of the rat GLUT4 protein and the carboxy terminal 16 amino acids (CKTPEELFHPLGADSQV) and amino acids 225-238 (CKSVLKKLRGTADVT) of the cytoplasmic loop of the rat GLUT1 protein were synthesized (Multiple Peptide Systems, San Diego, CA) and each coupled to keyhole limpet hemocyanin using the chemical cross-linking reagent sulfosuccinimidyl 4-( $N$-maleimido-methyl)-cyclohexane-1-carboxylate (Pierce Chemical Co., Rockford, IL) as described by Green et al. (45). For GLUT1 peptides, rabbits were immunized according to a previously published protocol (4). For GLUT4 peptides, rabbits were immunized by two subcutaneous injections separated by $4 \mathrm{wk}$ with a suspension of $1.0 \mathrm{mg}$ of the peptide conjugate in $2.0 \mathrm{ml}$ of Freunds complete adjuvant. 2 wk after the primary immunization the rabbits were given an intravenous booster containing $0.1 \mathrm{mg}$ of the peptide conjugate dissolved in $0.1-0.2$ $\mathrm{ml}$ of sterile PBS (pH 7.4). The intravenous boosters were subsequently administered at least two additional times at 3-4-d intervals. The animals were subsequently bled every $7 \mathrm{~d}$ for a period of 1 mo before useful antibodies were obtained.

To test the specificity and immunoreactivity of the antisera (designated MC1 B, corresponding to the amino terminus and MC2A, corresponding to the carboxy terminus) SP6 in vitro transcripts were prepared using a Dra I-Eco RI subclone of the rat GLUT4 CDNA (7) and injected into $X$. laevis oocytes with $50 \mathrm{nl}$ of mRNA (200-300 ng/liter) as previously described (46). Oocytes were labeled for $16 \mathrm{~h}$ with $\left({ }^{35} \mathrm{~S}\right) \mathrm{me}-$ thionine and membranes were prepared by the method of Colman (47). Samples were precleared with $10 \mu l$ of preimmune serum (30 $\mathrm{min}$ at room temperature) then $50 \mu$ l of Affi-Gel-protein A (Bio-Rad Laboratories, Richmond, $\mathrm{CA}$ ) for $30 \mathrm{~min}$. $10 \mu \mathrm{l}$ of immune serum was added to the supernatant and the samples were incubated at $4^{\circ} \mathrm{C}$ overnight. The immune complexes were removed, washed, and dissociated for SDSPAGE (10\%) as described (46). After autoradiography an $\sim 40-\mathrm{kD}$ polypeptide was immunoprecipitated (Garcia, A. M., and M. J. Charron, unpublished results).

Affinity purification of antisera for immunohistochemistry. Affinity purification of anti-GLUT4 (MC1B and MC2A) and anti-GLUT1 (R1B, corresponding to the carboxy terminus and R2A, corresponding to amino acids $225-238$ of the cytoplasmic loop) antisera was performed by chemical cross-linking the peptides to BSA using $m$-maleimidobenzoyl- $N$-hydroxysuccinimide ester (Pierce Chemical Co.) and linked to an Affi-Gel 15 matrix according to the manufacturers instructions (Bio-Rad Laboratories). Eluted IgG fractions were dialyzed against 4 liters of $\mathrm{PBS}$ at $4^{\circ} \mathrm{C}$ and protein concentration determined using the BCA assay (Pierce Chemical Co.).

Immunofluorescence microscopy. Soleus muscles were immediately frozen in either liquid nitrogen or 2-methylbutane and embedded in Tissue-Tek O.C.T. compound 4583 (Miles, Inc., Elkhart, IN) for sectioning. 4- $\mu \mathrm{m}$ transverse sections were cut and placed in ice-cold PBS. Nonspecific binding was blocked by incubation of the sections in $5 \%$ horse serum (Gibco, Grand Island, NY), $2 \%$ BSA, $50 \mu \mathrm{g} / \mathrm{ml}$ normal goat IgG (Zymed Laboratories, Inc., South San Francisco, CA) for 10 min at room temperature. All subsequent reactions were carried out at room temperature in the above blocking solution. Sections were incubated for 60 min with one of the following affinity purified antipeptide antisera: against the $\mathrm{COOH}$-terminal 16 amino acids of rat GLUT4 (10 $\mu \mathrm{g} / \mathrm{ml})$; against the $\mathrm{NH}_{2}$-terminal 13 amino acids of GLUT4 $(20 \mu \mathrm{g} /$ $\mathrm{ml})$; against the COOH-terminal 16 amino acids of GLUT1 $(10 \mu \mathrm{g} / \mathrm{ml})$; against cytoplasmic loop amino acids $225-238$ of GLUT1 $(10 \mu \mathrm{g} / \mathrm{ml})$; 
or against the $\mathrm{COOH}$-terminal 15 amino acids of the human asialoglycoprotein receptor $(20 \mu \mathrm{g} / \mathrm{ml})$ (a generous of Dr. G. Lederkremer, Whitehead Institute, Cambridge, MA) $(48,49)$. Thereafter, sections were washed four times with PBS (5 min/wash) and reacted for $30 \mathrm{~min}$ with 1:100 diluted fluoresceinated goat anti-rabbit IgG (Cappel Laboratories, Inc., West Chester, PA). The sections were then washed four times for $5 \mathrm{~min}$ in PBS and mounted in $60 \%$ glycerol, $2 \% n$-propyl gallate, 0.2 $\mathrm{M}$ Tris- $\mathrm{HCl}$ (pH 8.0). Incubations with affinity-purified antisera d10 (1:250 dilution) against human skeletal muscle dystrophin (a generous gift of Dr. E. Hoffman and Dr. L. Kunkel, Children's Hospital, Boston, MA) were as described previously (50). Sections were observed using Neofluor objectives on a Zeiss Photomicroscope III and photographed with Kodak T-Max 400 film.

\section{Preparation of total cellular membranes from skeletal muscle}

A total membrane preparation containing both plasma membranes and microsomes was prepared from $\sim 500 \mathrm{mg}$ of frozen muscle by a previously described modification $(21,51)$ of the protocol of Klip et al. (52). Similar amounts of red and white gastrocnemius muscle were included in each preparation with only small portions of soleus to maintain the proportions of muscle fiber type representative of those in hindlimb. Membrane protein concentrations were determined by a modification of the Bio-Rad Laboratories method (53) using BSA (Sigma Chemical Co.) as the standard.

\section{Detection of GLUT1 and GLUT4 by immunoblotting}

Membranes were subjected to $10 \%$ SDS-PAGE, electrophoretic transfer to nitrocellulose filters, and blockade with $5 \%$ nonfat milk. Equivalent loading and transfer of membrane protein from all lanes of the gel was verified by Ponceau red staining of the nitrocellulose filters and Coomassie Blue staining of the gels. Identical membranes were immunoblotted as previously described $(17,21)$ with a polyclonal antiserum prepared against a synthetic peptide consisting of the 16 carboxyl-terminal amino acids of GLUT1 (gift of Dr. B. Thorens, Whitehead Institute) at $10 \mu \mathrm{g} / \mathrm{ml}$ followed by ${ }^{125} \mathrm{I}$-protein A (New England Nuclear, Boston, MA) or with the monoclonal antibody 1F8 (gift of Dr. D. James, Washington University, St. Louis, MO) at $10 \mu \mathrm{g} / \mathrm{ml}$ followed by sheep antimouse ${ }^{125} \mathrm{I}-\mathrm{F}(\mathrm{ab})_{2}$ (Amersham Corp., Arlington Heights, IL).

\section{RNA isolation and Northern blot analysis}

RNA was extracted from $\sim 500 \mathrm{mg}$ of frozen muscle using the guanadinium thiocyanate/ $\mathrm{CsCl}$ method (54). RNA was electrophoresed on $1.2 \%$ formaldehyde-agarose gels, blotted, and fixed onto nylon membranes and then hybridized at high stringency to cRNA probes specific for GLUT1 (gift of Dr. M. Mueckler, Washington University) or for GLUT4 as previously described $(7,15,17,21)$. Filters were washed and exposed to autoradiography also as previously described $(7,15,17,21)$.

\section{DNA analysis}

DNA was determined on $\sim 500 \mathrm{mg}$ of muscle using the spectrofluorimetric method of Labarca and Paigen (55).

\section{Measurement of in vivo glucose disposal by euglycemic clamp studies}

Insulin-mediated whole body glucose uptake was measured in awake unstressed chronically catheterized rats using the euglycemic clamp in combination with $\left({ }^{3} \mathrm{H}-3\right)$-glucose infusion, as previously described $(31$, 56). Briefly, $2 \mathrm{~d}$ after streptozocin injection or sham-injection rats were anesthetized with an intraperitoneal injection of pentobarbital $(50 \mathrm{mg} /$ $\mathrm{kg}$ body weight) and indwelling catheters were inserted in the right internal jugular vein and in the left carotid artery. The venous catheter was extended to the level of the right atrium and the arterial catheter was advanced to the level of the aortic arch $(31,56) .5 \mathrm{~d}$ after catheter placement ( 1 wwk poststreptozocin) rats $(n=5)$ received an infusion of insulin at $18 \mathrm{mU} / \mathrm{kg}$ min for $2 \mathrm{~h}$. A variable infusion of $25 \%$ glucose solution was started at time 0 and adjusted to clamp the plasma glucose concentration at $\sim 110 \mathrm{mg} / \mathrm{dl}$. A prime-continuous $(0.4 \mu \mathrm{Ci} / \mathrm{min})$ infusion of $\left({ }^{3} \mathrm{H}-3\right)$-glucose (New England Nuclear) was initiated at time zero and continued throughout the study $(57,58)$. Plasma samples for determination of $\left({ }^{3} \mathrm{H}-3\right)$-glucose and tritiated water specific activities were obtained at 5-10-min intervals throughout the insulin clamp study. Plasma samples for determination of plasma insulin concentrations were obtained at $-30,0,60,90,120$ min during the study. The total volume of blood withdrawn was $<3.0 \mathrm{ml} /$ study; to prevent volume depletion and anemia, insulin was diluted in a solution (1:1 vol/ $\mathrm{vol}$ ) of $4.0 \mathrm{ml}$ of fresh blood (obtained by heart puncture from a littermate of the test animal) and heparinized saline $(10 \mathrm{U} / \mathrm{ml})$. At the end of the 120 -min study rats were injected with pentobarbital $(60 \mathrm{mg} / \mathrm{kg}$ body wt), the abdomen was quickly opened, the rectus abdominal muscle was freeze-clamped in situ and then the hindlimb muscle was freeze-clamped with aluminum tongs precooled in liquid nitrogen. All tissue samples were kept frozen at $-80^{\circ} \mathrm{C}$ for subsequent analysis. The study protocol was reviewed and approved by the Institutional Animal Care and Use Committees of the University of Texas Health Science Center at San Antonio and of Beth Israel Hospital, Boston, MA.

\section{Glycogen formation in muscle in vivo}

Muscle glycogen synthesis was quantitated by two independent means: first, by determining the increment in glycogen concentration above fasting levels, and second, by measuring the incorporation of $\left({ }^{3} \mathrm{H}-3\right)$ glucose into glycogen. Muscle glycogen concentration was determined after digestion with amyloglucosidase as previously described $(59,60)$. The intraassay and the interassay coefficients of variation (CV) were $<10 \%$ (at $0.250 \mathrm{~g} \%$ tissue wt). Aliquots of the tissue homogenate (200 $\mu l)$ were employed to determine the amount of tritium label in glycogen. To isolate glycogen from free glucose, glycogen was precipitated by adding $10 \mathrm{vol}$ of absolute ethanol and incubating for $1 \mathrm{~h}$ at $-20^{\circ} \mathrm{C}$. The procedure was repeated three times and then the precipitate was collected, dried, and dissolved in water before scintillation counting. The recovery of free $\left({ }^{3} \mathrm{H}-3\right)$-glucose, added to test the procedure, was $<1 \%$ of the free glucose radioactivity added to the homogenate in each assay. The glycogen synthetic rate was obtained by dividing the $\left({ }^{3} \mathrm{H}-3\right)$-glucose radioactivity in glycogen (disintegrations per minute per milligram tissue) by the mean specific activity of $\left({ }^{3} \mathrm{H}-3\right)$-glucose in plasma during the insulin clamp (disintegrations per minute per milligram plasma glucose). The rate of net glycogen synthesis is expressed as milligrams of glucose in glycogen per gram of tissue. During the initial 30 min after starting insulin, the plasma tritiated glucose specific activity is not constant and blood was drawn every 5 min to define accurately the mean specific activity during this time period. This number was time-averaged with the mean tritiated glucose during the last $90 \mathrm{~min}$ of the insulin clamp to calculate the glycogen synthetic rate.

\section{Whole body glycolytic flux in vivo}

Aliquots of plasma were precipitated with $\mathrm{Ba}(\mathrm{OH})_{2}$ and $\mathrm{ZnSo}_{4}$ and centrifuged. Plasma tritiated water specific activity was determined by liquid scintillation counting of the protein-free supernatant (Somogyi filtrate) before and after evaporation to dryness. Because tritium on the C-3 position of glucose is lost to water during glycolysis, it can be assumed that plasma tritium is present either in tritiated water or $\left({ }^{3} \mathrm{H}-\right.$ 3 )-glucose (61). Although tritium may also be released during fructose6-phosphate cycling and/or pentose phosphate cycling, these pathways account for only a small percentage of glucose turnover (62-64). Additionally, some of the glucose carbons which enter the pentose phosphate pathway will reenter the glycolytic pathway through glyceraldehyde and will be correctly interpreted as glycolytic flux with the present methodology. Rates of whole body glycolysis were estimated from the increment per unit time in tritiated water (disintegrations per minute per milliliters $\cdot$ minute) $\times$ body water mass (milliliters) $/\left({ }^{3} \mathrm{H}-3\right)$-glucose specific activity (disintegrations per minute/milligram). Plasma water was assumed to be $93 \%$ of the total plasma volume and total body water mass was assumed to be $65 \%$ of the body mass. The loss of tritiated water in the urine can affect the calculation of the whole body glycolysis in proportion to the difference in specific activity with the sampling 
compartment (i.e., plasma). The tritiated water specific activity was measured in the urine at the end of each study and was $>85 \%$ of the plasma specific activity in all studies. The urine loss during the study is $<3 \mathrm{ml}$ (=1.5\% of the water distribution space). The maximal error introduced in the calculation is therefore $0.002(0.15 \times 0.015)$ or $0.2 \%$.

\section{Analytical procedures}

Muscle G-6-P was measured spectrophotometrically as described by Michal (65). For rats which underwent euglycemic clamp studies, plasma glucose was measured by the glucose oxidase method (Glucose Analyzer; Beckman Instruments, Inc., Palo Alto, CA) and plasma insulin by radioimmunoassay using rat and porcine insulin standards. Plasma $\left({ }^{3} \mathrm{H}-3\right)$-glucose radioactivity was measured in duplicate on the supernatants of barium hydroxide-zinc sulphate precipitates (Somogyi procedure) of plasma samples after evaporation to dryness to eliminate tritiated water.

\section{Calculations}

Data for total body glucose uptake and suppression of hepatic glucose production represent the mean values during the last $30 \mathrm{~min}$. Hepatic glucose production was calculated as the difference between the tracerderived rate of appearance and the infusion rate of glucose. Total body glucose disposal was calculated by adding the rate of residual hepatic glucose production during the last $30 \mathrm{~min}$ of each insulin clamp to the glucose infusion rate during the same $30 \mathrm{~min}$ time period. The rate of net glycogen synthesis was calculated as number of $\left({ }^{3} \mathrm{H}-3\right)$-glucose disintegrations per minute in glycogen per gram of muscle tissue divided by the time-weighed means plasma $\left({ }^{3} \mathrm{H}-3\right)$-glucose specific activity (disintegrations per minute per milligram glucose). For each rat the mean of four determinations on rectus abdominal muscle and four on hindlimb muscle were employed to approximate the mean whole body muscle glycogen concentration. The whole body glycolytic rate was calculated from the increment per minute in plasma ${ }^{3} \mathrm{H}_{2} \mathrm{O}$ radioactivity from 60 to 120 min multiplied by the body water space and divided by the $\left({ }^{3} \mathrm{H}-3\right)$-glucose specific activity. This time period was selected because the appearance in ${ }^{3} \mathrm{H}_{2} \mathrm{O}$ counts in the plasma became linear 40-50 min after $\left({ }^{3} \mathrm{H}-3\right)$-glucose infusion (SG).

\section{Statistical analysis}

Statistical analyses were performed on the Beth Israel Hospital analyzer system. Differences between groups were determined using analysis of variance in conjunction with the Newman-Keuls test. For densitometry data a one-sample comparison test was used because these results are evaluated as a percent of control due to the arbitrary nature of $O D$ units. Differences were accepted as significant at the $P \leq 0.05$ level.

\section{Results}

Rat body weight and blood glucose concentration. Control rats weighed 290-316 g at sacrifice. Body weight was reduced 15$20 \%$ in $7-\mathrm{d}$ diabetic rats and $40-55 \%$ in $14 \mathrm{~d}$ diabetic rats. Insulin therapy increased the rate of weight gain compared to untreated diabetic rats but did not restore body weight to normal, confirming previous results (44). Blood glucose was $>25$ $\mathrm{mM}$ in all diabetic rats and $>33 \mathrm{mM}$ in most diabetic rats. Insulin therapy for 3,5 , and $7 \mathrm{~d}$ restored blood glucose to normal or slightly below in the fasted and fed states.

$D N A$, membrane protein, and RNA content of muscle. Table I shows DNA per gram of muscle tissue, membrane protein per gram of muscle and per microgram DNA, and RNA per gram of muscle and per microgram DNA in all groups of rats. Neither DNA nor membrane protein per gram of muscle tissue is altered by diabetes or insulin treatment. However, when expressed per microgram DNA, membrane protein is 30\% decreased in 14-d diabetic rats but unchanged after $7 \mathrm{~d}$ of diabetes or 3,5 , or $7 \mathrm{~d}$ of insulin treatment. RNA expressed either per gram of muscle tissue or per microgram DNA is $34-39 \%$ decreased in 7-d diabetic rats and further decreased after $14 \mathrm{~d}$ of diabetes. After 3 and $5 \mathrm{~d}$ of insulin therapy, the amount of RNA is not only restored but increased $30 \%$ above control when expressed per microgram DNA. By $7 \mathrm{~d}$ of insulin therapy the RNA/DNA ratio returns to control levels.

Table I. DNA, Membrane Protein, and RNA Content and Glucose Transporter Expression in Skeletal Muscle of Control, Diabetic, and Insulin-treated Diabetic Rats

\begin{tabular}{|c|c|c|c|c|c|c|}
\hline & \multirow[b]{2}{*}{ Control } & \multicolumn{2}{|c|}{ Diabetic } & \multicolumn{3}{|c|}{ Diabetic/Insulin } \\
\hline & & $7 d$ & $14 \mathrm{~d}$ & $3 \mathrm{~d}$ & $5 d$ & $7 \mathrm{~d}$ \\
\hline $\begin{array}{l}\text { DNA/g of muscle } \\
\quad(\mu g / g)\end{array}$ & $\begin{array}{c}100 \\
(921 \pm 137)\end{array}$ & $102 \pm 7$ & $140 \pm 24$ & $77 \pm 5$ & $86 \pm 8$ & $116 \pm 11$ \\
\hline $\begin{array}{l}\text { Membrane protein/ } \\
\text { g of muscle }(\mathrm{mg} / \mathrm{g})\end{array}$ & $\begin{array}{c}100 \\
(6.96 \pm 0.9)\end{array}$ & $119 \pm 13$ & $95 \pm 17$ & $84 \pm 11$ & $96 \pm 5$ & $109 \pm 7$ \\
\hline $\begin{array}{l}\text { Membrane protein/ } \\
\text { DNA }(\mu g / \mu g)\end{array}$ & $\begin{array}{c}100 \\
(6.90 \pm 1.7)\end{array}$ & $127 \pm 17$ & $71 \pm 2^{*}$ & $109 \pm 8$ & $115 \pm 16$ & $96 \pm 13$ \\
\hline $\begin{array}{l}\text { RNA/g of muscle } \\
(\mu g / g)\end{array}$ & $\begin{array}{c}100 \\
(220 \pm 12)\end{array}$ & $61 \pm 2^{*}$ & $59 \pm 7^{*}$ & $99 \pm 3$ & $108 \pm 7$ & $114 \pm 9$ \\
\hline $\begin{array}{l}\text { RNA/DNA } \\
(\mu g / \mu g)\end{array}$ & $\begin{array}{c}100 \\
(0.208 \pm 0.02)\end{array}$ & $66 \pm 7^{*}$ & $49 \pm 10^{*}$ & $130 \pm 3^{*}$ & $128 \pm 3^{*}$ & $103 \pm 16$ \\
\hline $\begin{array}{l}\text { GLUT4 protein } / \mu \mathrm{g} \text { of membrane } \\
\text { protein }(O D / \mu g)\end{array}$ & 100 & $79 \pm 13$ & $27 \pm 7^{*}$ & $59 \pm 2^{*}$ & $86 \pm 22$ & $86 \pm 10$ \\
\hline $\begin{array}{l}\text { GLUT4 mRNA/ } / \mu \mathrm{g} \text { of RNA } \\
(O D / \mu g)\end{array}$ & 100 & $57 \pm 9^{*}$ & $61 \pm 1^{*}$ & $142 \pm 14$ & $102 \pm 35$ & $93 \pm 25$ \\
\hline $\begin{array}{l}\text { GLUT1 protein } / \mu \mathrm{g} \text { of membrane } \\
\text { protein }(O D / \mu g)\end{array}$ & 100 & $86 \pm 39$ & $38 \pm 5^{*}$ & $122 \pm 10$ & - & $96 \pm 36$ \\
\hline $\begin{array}{l}\text { GLUT1 mRNA/ } 1 \mathrm{~g} \text { of RNA } \\
(O D / \mu g)\end{array}$ & 100 & $58 \pm 5^{*}$ & $75 \pm 11$ & $123 \pm 10$ & $81 \pm 17$ & $71 \pm 10$ \\
\hline
\end{tabular}

Values are means \pm SEM of results from three to eight rats per experimental condition. All values are expressed as percent of control. The numbers in parentheses are the control values in designated units. ${ }^{*}$ Significant difference from control at $P \leq 0.05$. 
Immunolocalization of GLUT1 and GLUT4 in rat soleus muscle. Fig. 1 shows the immunohistochemical localization of GLUT1 and GLUT4 in soleus muscle from normal rats, using affinity-purified polyclonal antisera against peptides of the rat GLUT1 and GLUT4 gene products (see Methods). GLUT1 is detected exclusively in cells associated with blood vessels, pre- sumably perineurial cells and not in muscle fibers (Fig. $1 A$ ); an identical staining pattern is observed using affinity-purified antipeptide antisera against the cytoplasmic loop of GLUT1 (aa 225-238) (not shown). Some staining is also detected on erythrocytes. Staining is not detected when the antisera are preincubated with $0.1 \mathrm{mg} / \mathrm{ml}$ of the immunizing peptide (not shown).
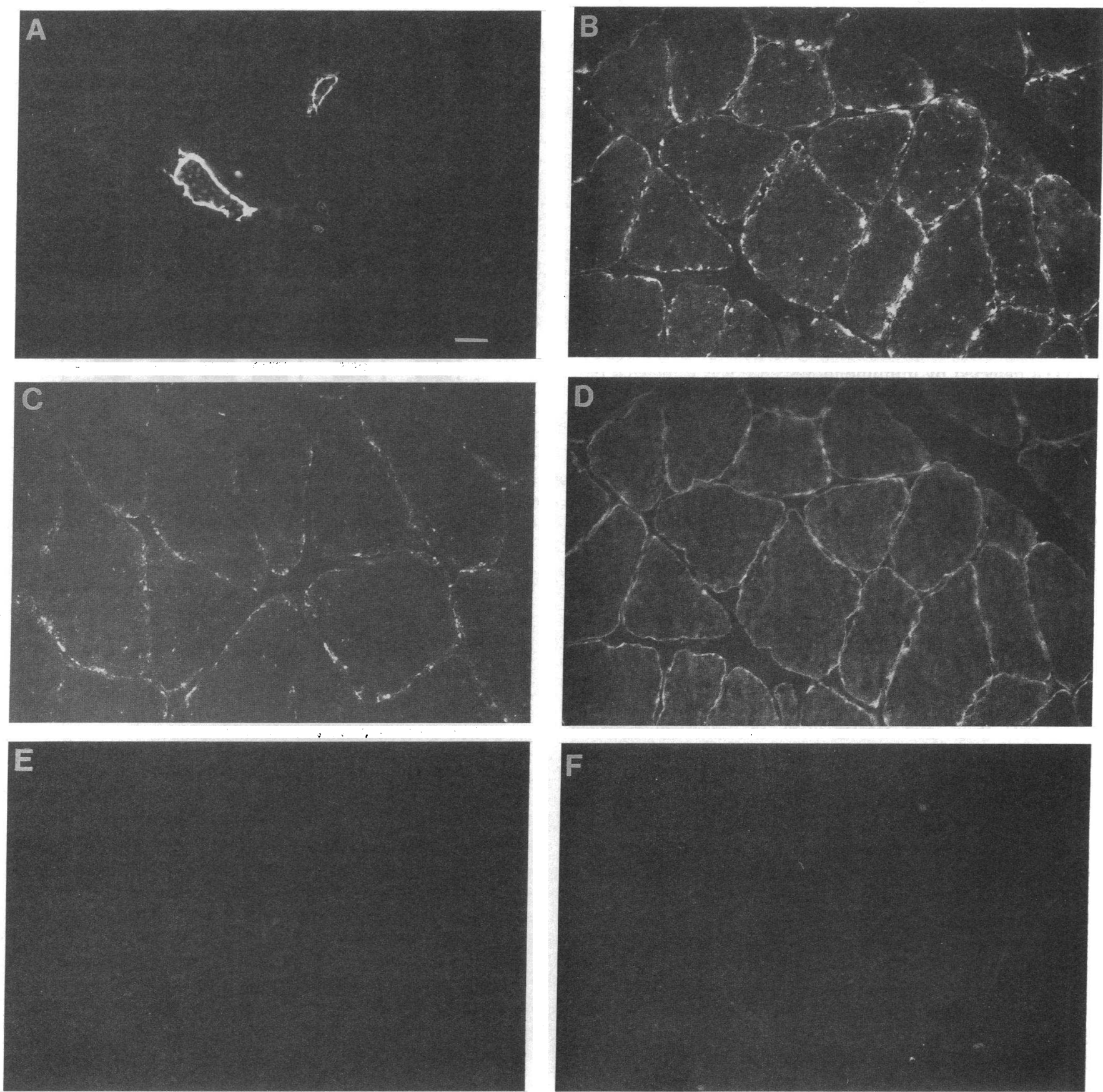

Figure 1. Immunohistochemical localization of GLUT1 and GLUT4 in skeletal muscle. Muscle was prepared, antisera were raised and affinity purified, and immunofluorescence was performed as described in Methods. Transverse sections through normal rat soleus muscle are shown in $A-F$. (A) GLUT1, detected with a carboxy terminal antiserum, is localized to cells associated with blood vessels, presumably perineurial cells. $(B$ and $C)$ GLUT4, detected with antisera to both the carboxy $(B)$ and amino $(C)$ termini, is present in all muscle cells examined. $(D)$ Dystrophin, detected with antiserum d10 localizes to sarcolemma (50). Comparison of $B$ and $D$ shows colocalization of GLUT4 and dystrophin in the sarcolemma with GLUT4 exhibiting a punctate pattern also seen within the muscle fiber. $(E)$ Incubation of muscle sections with $\mathrm{H} 1$ antiserum against the human asialoglycoprotein receptor results in no staining. $(F)$ Competition for antibody binding with a peptide consisting of the carboxy terminal 16 amino acids of GLUT4 inhibits staining. Bar, $20 \mu \mathrm{m}$. Each panel is representative of sections from >12 different rats. 
In contrast, GLUT4 is expressed at or near the sarcolemma in a nonuniform pattern, as detected with antibodies against both $\mathrm{COOH}$ - and $\mathrm{NH}_{2}$-terminal peptides (Fig. $1, B$ and $C$ ). GLUT4 is also detected in more internal portions of the muscle fiber. Preincubation of these antisera with $0.1 \mathrm{mg} / \mathrm{ml}$ of the immunizing peptide abolished all staining (Fig. $1 F$ ). To confirm the localization of GLUT4 to the sarcolemma we double stained the same section using an affinity-purified polyclonal antipeptide antibody specific for dystrophin which localizes to the sarcolemma (50) and observed overlap in the staining patterns (Fig. $1, B$ and $D$ ). Fig. $1, B$ and $D$, suggest that GLUT4 is present in the sarcolemma and may also be present in subsarcolemma vesicles as was also recently shown by Slot et al. (43). As an additional control, we incubated muscle sections with affinity-purified polyclonal antipeptide antisera specific for the H1 subunit of the human asialogycoprotein receptor, a liverspecific protein $(48,49)$. No staining was detected, as predicted (Fig. $1 E$ ). Localization of both GLUT1 and GLUT4 was confirmed using sections from $>12$ rats for each antiserum with invariant results.

The localization of GLUT1 and GLUT4 by immunofluorescence staining was unaltered by diabetes or insulin treatment. In skeletal muscle of 14-d diabetic rats, the amount of GLUT4 detected by immunofluorescence was somewhat decreased compared with control and insulin-treated rats (not shown). To further evaluate this effect we performed more quantitative immunoblotting studies with antipeptide antisera (see below).

Expression of GLUT4 in muscle of diabetic rats before and after insulin treatment. Fig. $2 \mathrm{~A}$ shows immunoblotting of muscle membranes from diabetic and insulin-treated rats with an anti-GLUT4 antibody which recognizes a single band of 45-47 $\mathrm{kD}$. GLUT4 levels are unchanged at $7 \mathrm{~d}$ of diabetes but markedly decreased after $14 \mathrm{~d}$ of diabetes. With insulin treatment for 3,5 , or $7 \mathrm{~d}$, GLUT4 protein levels are unchanged or even slightly decreased compared with control. The values from multiple experiments quantitated by scanning densitometry are shown in Fig. $2 B$ and are compared to GLUT4 levels in adipose cells from rats treated with the identical protocol (previously reported, reference 17). The data in adipose cells are expressed per cell and those in muscle per microgram DNA, which is proportional to cell number. GLUT4 protein in muscle is unchanged after $7 \mathrm{~d}$ of diabetes, whereas levels in adipose cells decrease $87 \%$. In contrast, after $14 \mathrm{~d}$ of diabetes GLUT4 levels in muscle are decreased $80 \%$. This decrease between 7 and $14 \mathrm{~d}$ of diabetes is partially prevented by $3 \mathrm{~d}$ of insulin treatment after $11 \mathrm{~d}$ of diabetes and completely prevented with 5 and $7 \mathrm{~d}$ of insulin treatment after 9 and $7 \mathrm{~d}$ of diabetes, respectively. After $7 \mathrm{~d}$ of insulin treatment GLUT4 levels in adipose cells are restored to normal from the depressed level at $7 \mathrm{~d}$ of untreated diabetes. GLUT4 protein levels expressed per milligram of muscle membrane protein (Table I) are similar to those expressed per microgram DNA (Fig. 2 B) because muscle membrane protein expressed per microgram DNA is not significantly altered except after $14 \mathrm{~d}$ of diabetes. The $\sim 30 \%$ decrease in membrane protein/DNA at this 14-d time point makes GLUT4 levels/DNA (Fig. 2 B) $\sim 30 \%$ less than when expressed per milligram of membrane protein $(\mathrm{Ta}-$ ble I).

Fig. $3 A$ shows GLUT4 mRNA levels in muscle from these same rats. At 7 and $14 \mathrm{~d}$ of diabetes GLUT4 mRNA levels are significantly decreased. These levels are not only restored but
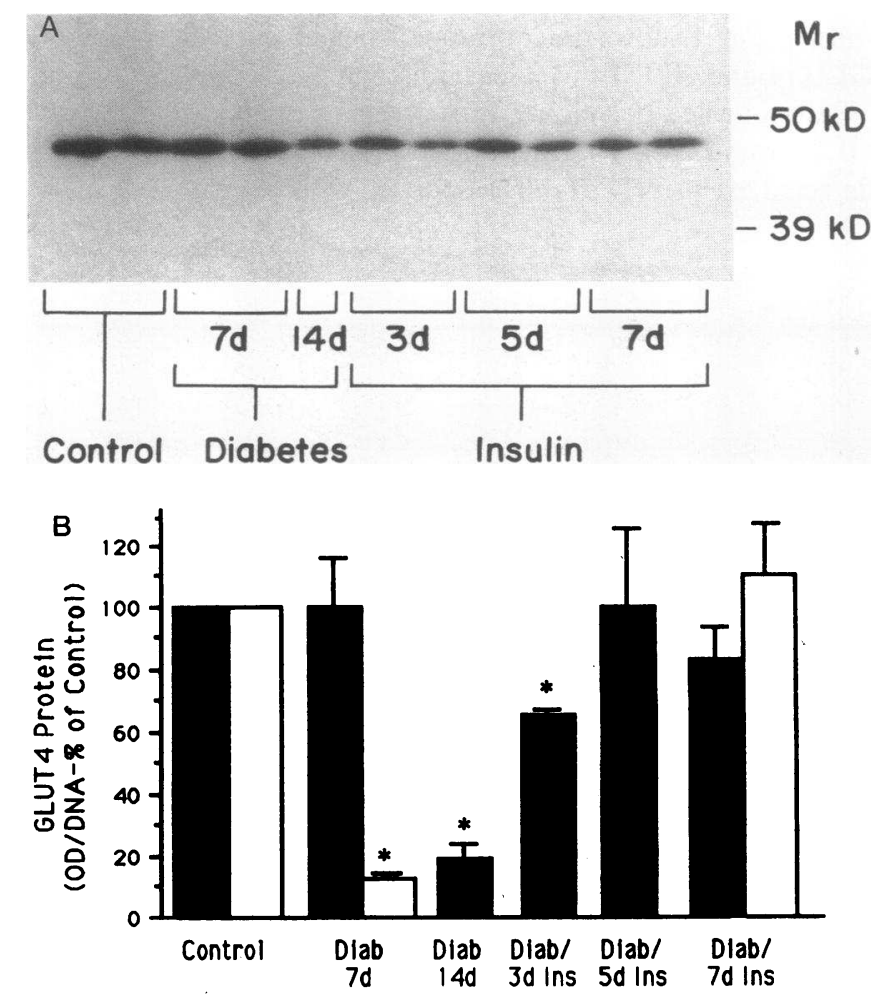

Figure 2. Effects of diabetes (Diab) and insulin treatment (Ins) on immunoreactive GLUT4 in skeletal muscle ( $₫$ ). Rats were rendered diabetic with streptozocin and treated with insulin; total muscle membranes were prepared and immunoreactive GLUT4 were detected as described in Methods. The immunoblot in $A$ is representative of three to four separate experiments each using one to two rats for each time point. Each lane contains $100 \mu \mathrm{g}$ of membrane protein from gastrocnemius and soleus muscles from a single rat. $B$ shows densitometric scanning of results from three to eight rats for each time point. For control, $7 \mathrm{~d}$ diabetic and $7 \mathrm{~d}$ insulin-treated, six to eight rats were used per time point. Optical density units per milligram membrane protein are divided by microgram DNA per milligram membrane protein (Table I) to yield optical density units per microgram DNA. GLUT4 abundance per adipose cell ( $($ ) (17) in 7-d diabetic and 7-d insulin-treated rats are shown for comparison. Results are means \pm SEM. ${ }^{*}$ Difference from control at $P \leq 0.05$.

increased above control levels after $3 \mathrm{~d}$ of insulin treatment and return to control levels at 5 and $7 \mathrm{~d}$ of insulin treatment. Quantitation of several experiments (Fig. $3 B$ ) shows that GLUT4 mRNA levels/DNA are decreased $63 \%$ at $7 \mathrm{~d}$ of diabetes and $70 \%$ at $14 \mathrm{~d}$ of diabetes. Levels are increased to $185 \%$ of control at $3 \mathrm{~d}$ of insulin therapy and return to control levels after 5 and $7 \mathrm{~d}$ of insulin. GLUT4 mRNA levels in adipose cells are similarly decreased at $7 \mathrm{~d}$ of diabetes but are increased nearly sevenfold after $7 \mathrm{~d}$ of insulin. The decrease in RNA/DNA (Table I) in diabetic rats makes the GLUT4 mRNA levels expressed per microgram DNA (Fig. $3 \mathrm{~B}$ ) even lower than that per microgram of RNA (Table I). However, the interpretation of the GLUT4 mRNA results is the same whether expressed per DNA or per RNA.

Expression of GLUT1 in muscle of diabetic rats before and after insulin treatment. Similar to the results for GLUT4, levels of the GLUT 1 protein in muscle were unaltered in $7 \mathrm{~d}$ diabetic rats and $\sim 70 \%$ decreased in $14 \mathrm{~d}$ diabetic rats (data not shown). (Recall that GLUT1 is expressed nearly exclusively in 

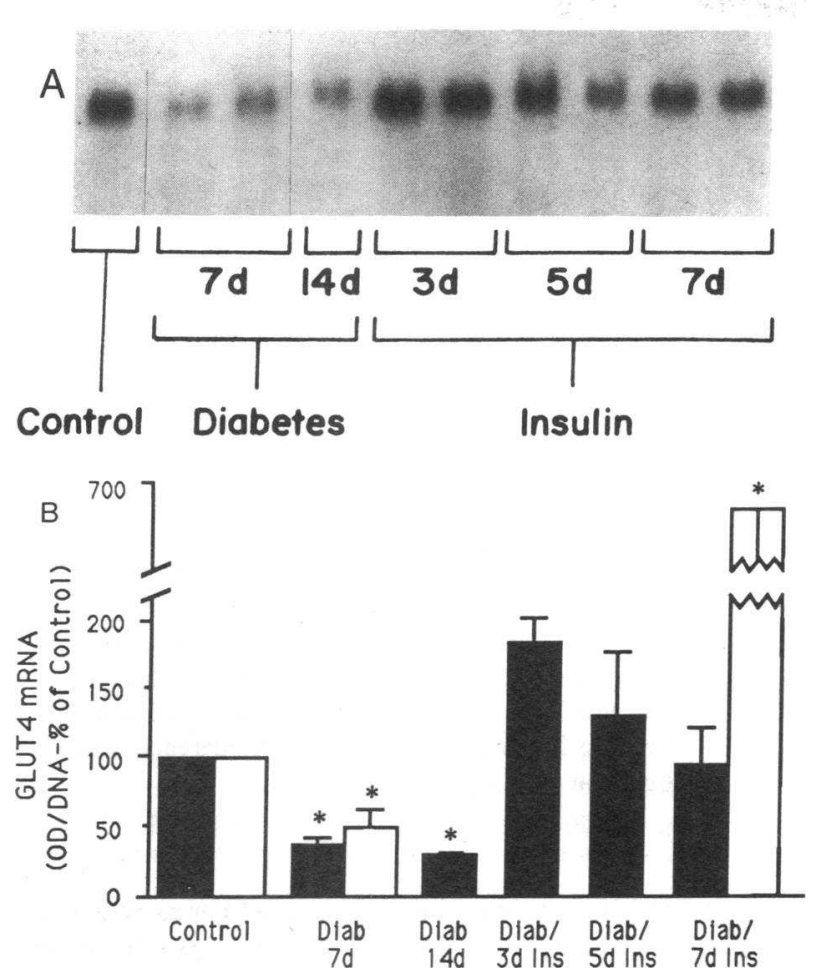

Figure 3. Effects of diabetes (Diab) and insulin treatment (Ins) on GLUT4 mRNA levels in skeletal muscle (ø). RNA was extracted and Northern blots were performed and probed as described in Methods. The Northern blot in $A$ is representative of three to four separate experiments for each time point using the same rats described for Fig. 2. $B$ shows densitometric scanning of results from three to five rats for each time point. Optical density units per microgram of RNA (Table I) are divided by RNA/DNA to yield optical density units per microgram DNA. GLUT4 mRNA levels per adipose cell (ㅁ) (17) in 7-d diabetic and 7-d insulin-treated rats are shown for comparison. Results are means \pm SEM. ${ }^{*}$ Difference from control at $P \leq 0.05$.

nonmuscle cells [Fig. 1]). This decrease in levels of GLUT1 protein between 7 and $14 \mathrm{~d}$ of diabetes is prevented by 3,5 , and $7 \mathrm{~d}$ of insulin treatment. Fig. 4 shows GLUT1 mRNA levels in muscle from the same rats compared to GLUT1 mRNA levels in adipose cells. GLUT1 mRNA/DNA in muscle is decreased $\sim 62 \%$ in 7 and $14 \mathrm{~d}$ diabetic rats, increased to $160 \%$ of control levels with $3 \mathrm{~d}$ of insulin treatment, and restored to control levels at 5 and $7 \mathrm{~d}$ of insulin. In contrast in adipose cells GLUT1 mRNA levels are unaltered at $7 \mathrm{~d}$ of diabetes and are increased to $300 \%$ of control with $7 \mathrm{~d}$ of insulin treatment.

In vivo glucose disposal and glucose metabolism in muscle of $7 d$ diabetic rats. Because levels of GLUT1 and GLUT4 proteins were unaltered in muscle of 7-d diabetic rats, we performed euglycemic clamp studies to determine whether these rats were resistant to the stimulatory effects of insulin on glucose uptake in vivo. During the insulin clamp study, plasma insulin concentrations were $523 \pm 38 \mu \mathrm{U} / \mathrm{ml}$ in control and $559 \pm 22 \mu \mathrm{U} / \mathrm{ml}$ in diabetic. Fig. $5 A$ shows that insulin-stimulated glucose disposal in vivo is reduced $46 \%$ in $7-\mathrm{d}$ diabetic rats compared to nondiabetic control rats $(37.5 \pm 1.2$ vs. $20.2 \pm 1.8$ $\mathrm{mg} / \mathrm{kg} \times \mathrm{min})$. This involves both a defect in glycolysis which is decreased $43 \%(19.9 \pm 0.9$ vs. $11.3 \pm 0.8)$ (Fig. $5 B$ ) and in muscle glycogen synthesis which is decreased $49 \%$ (13.4 \pm 0.9 vs. $6.8 \pm 1.4$ ) (Fig. $5 C$ ) in response to insulin. The relative contri- bution of glycolysis and glycogen synthesis to total insulinstimulated glucose uptake is similar in control and 7-d diabetic rats (Fig. 5 D). Skeletal muscle G-6-P levels are reduced 30\% in 7-d diabetic rats ( $473 \pm 24$ vs. $342 \pm 19 \mathrm{nmol} / \mathrm{g}$ wet $\mathrm{wt}$ )(Fig. 6). Severe hepatic insulin resistance is also present because during insulin infusion, hepatic glucose production is increased 7.5fold in $7-\mathrm{d}$ diabetic rats $(0.6 \pm 0.3$ vs. $4.5 \pm 1.3 \mathrm{mg} / \mathrm{kg} \times \mathrm{min})$.

\section{Discussion}

Diabetes in experimental animals (31-35) and humans (2729 ) is associated with in vivo insulin-resistant glucose uptake. Muscle is the major tissue responsible for insulin-mediated glucose uptake $(25,26)$. Reports of insulin-stimulated glucose uptake in isolated muscle from diabetic rodents show conflicting results. In isolated hindlimb muscles from streptozocin diabetic and spontaneously diabetic rodents, maximal insulinstimulated glucose transport was decreased (34-36) or normal $(22,32)$ and the sensitivity to insulin was increased $(22)$. Perfused hindlimb studies in diabetic rats failed to show insulin-resistant glucose uptake (33) except in the presence of ketosis (24). Even in studies demonstrating diminished glucose transport in response to insulin in muscle of diabetic rats, the defect was reversed with incubation of the isolated muscle in KrebsHenseleit bicarbonate buffer (34) suggesting that circulating factors in vivo may inhibit glucose uptake in muscle. Thus, the mechanism(s) for in vivo insulin-resistant glucose uptake in diabetes are unclear.

The rate limiting step for insulin-mediated glucose uptake in vivo has been examined by several methodological approaches $(26,66-71)$ which have been discussed (56). Trans-
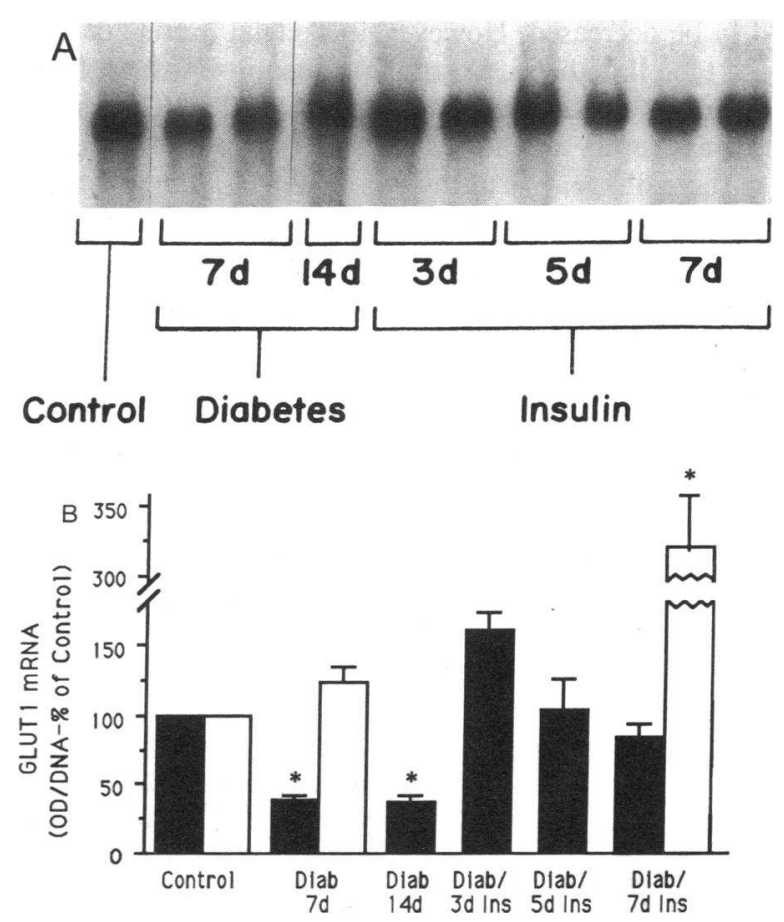

Figure 4. Effects of diabetes (Diab) and insulin treatment (Ins) on GLUT1 mRNA levels in skeletal muscle ( $\square$ ) and adipose cells ( $\square$ ) (17). The same methods and rats were used as in Fig. 3. Results are means \pm SEM. *Difference from control at $P \leq 0.05$. 

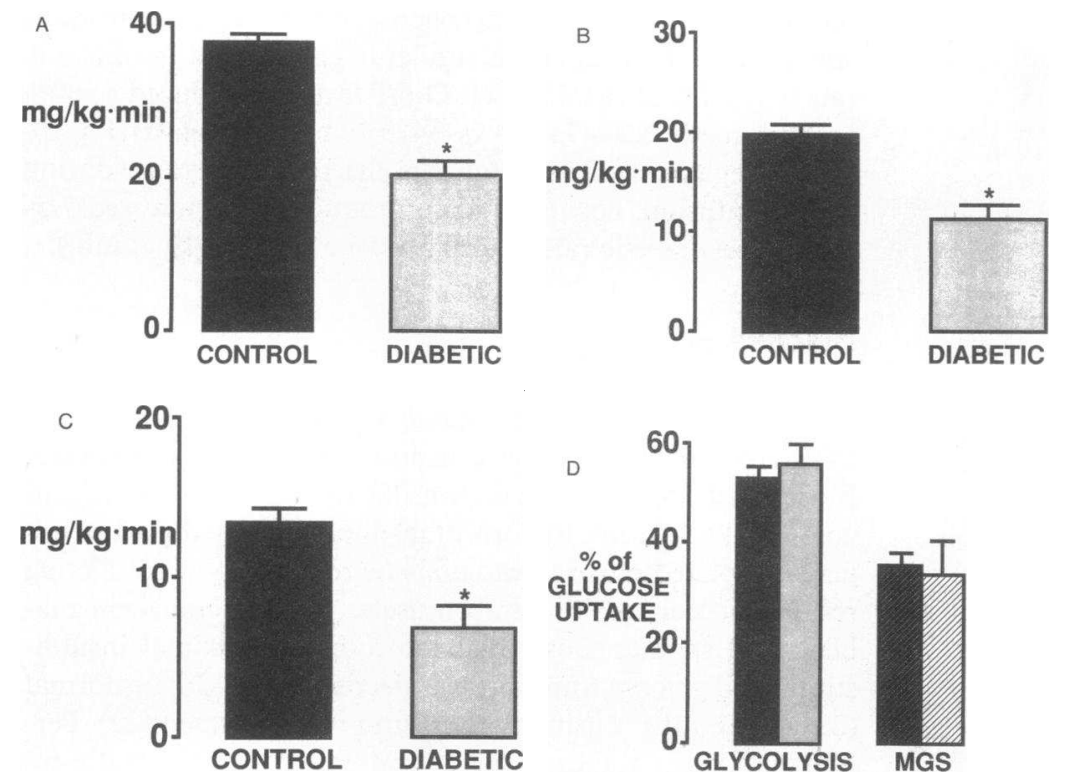

Figure 5. Effects of $7 \mathrm{~d}$ of diabetes on whole body insulin-mediated glucose uptake $(A)$, glycolysis $(B)$, muscle glycogen synthesis $(C)$ and the relative contributions of glycolysis and muscle glycogen synthesis (MGS) to in vivo glucose uptake $(D)$. Glucose uptake, glycolysis, and muscle glycogen synthesis were measured in awake rats by the insulin ( $18 \mathrm{mU} / \mathrm{kg}$ per $\mathrm{min}$ ) clamp technique as described in Methods. Results are means \pm SEM of values from five rats for each group. ${ }^{*}$ Difference from control at $P \leq 0.05$.

port is rate limiting for glucose utilization at physiological glucose concentrations with insulin concentrations in the low-tomoderate physiological range $(26,56)$. In addition, glucose transport is rate limiting for glucose utilization in skeletal muscle in humans with type I diabetes (71) and in streptozocin diabetic rats (70). Thus, a defect in expression of GLUT4 in skeletal muscle could potentially explain the in vivo insulin-resistant glucose uptake which is characteristic of all models of diabetes studied. In hindlimb muscle of streptozocin diabetic rats, glucose transporter number measured by cytochalasin $B$ binding (72) and with an anti-GLUT4 antibody (73) have been reported to be decreased. However, in skeletal muscle of humans with type II diabetes, a prototypic insulin-resistant state, GLUT1 and GLUT4 expression is not altered (51). This raises the question whether alterations in GLUT4 expression are essential to the pathogenesis of in vivo insulin resistance. Many of the previous studies are limited by being performed at only one time point and after diabetes is well established. This precludes evaluation of the events involved in the development of insulin resistance and leaves open the possibility that impaired expression of GLUT4 may be a sequela of the catabolic or hyperglycemic state. In this study we show that in vivo insulin resistance can be present without alteration in GLUT4 polypeptide levels in skeletal muscle.

First, we use immunofluorescence to confirm that GLUT4, not GLUT1, is likely to be the major transporter responsible for insulin-stimulated glucose transport in normal and diabetic

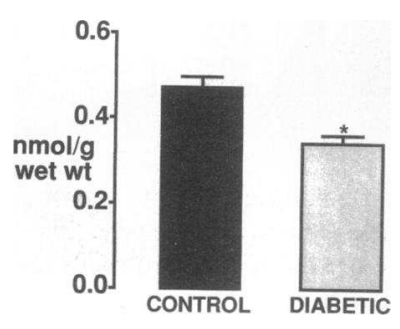

Figure 6. Effects of $7 \mathrm{~d}$ of diabetes on concentrations of G-6-P in skeletal muscle of rats at the end of the insulin $(18 \mathrm{mU} / \mathrm{kg}$ per $\mathrm{min})$ clamp study. G-6-P was measured in situ in freeze clamped muscle as described in Methods. Results are means \pm SEM of values from five rats for each group. *Difference from control at $P \leq 0.05$. muscle. GLUT4 is present within the muscle fiber as evidenced by its colocalization with dystrophin, which is present in the plasma membrane in muscle (50) (Fig. 1, B and $D$ ). Our findings are in agreement with a recent study (43) using immunogold labeling which localized GLUT4 to muscle fibers. In contrast, GLUT1 appears to be confined to the perineurial sheath in skeletal muscle (Fig. $1 \mathrm{~A}$ ) as has previously been shown in diaphragm (41). These findings do not rule out the possibility that GLUT1 is present within muscle fibers because either low level expression or masking of epitopes would yield results similar to those in Fig. $1 \mathrm{~A}$. Masking of epitopes is unlikely, however, because the same staining pattern was seen with antisera against the carboxy terminus and the cytoplasmic loop of GLUT1.

Immunoblotting shows that GLUT1 and GLUT4 protein levels are not diminished after $7 \mathrm{~d}$ of diabetes but are markedly decreased after $14 \mathrm{~d}$ (Fig. 2). Insulin treatment after $7 \mathrm{~d}$ of diabetes prevents these decreases. This is consistent with a previous study which showed normal insulin-stimulated glucose transport in soleus muscle of $7 \mathrm{~d}$ diabetic rats but progressively decreased transport at 14 and $21 \mathrm{~d}(74)$. GLUT1 and GLUT4 mRNA levels are reduced at both 7 and $14 \mathrm{~d}$ of diabetes. Thus, important regulation of GLUT1 and GLUT4 expression occurs posttranscriptionally. We previously showed a similar discordance in glucose transporter protein and mRNA levels in adipose cells of insulin-treated diabetic rats (17) and in liver from fasted and refed rats (75). As we recently showed in fasted rats (21), regulation of GLUT1 and GLUT4 is tissue specific (Fig. $2 B$ ). That is, at $7 \mathrm{~d}$ of diabetes, GLUT4 protein in adipose cells is markedly decreased while it is unaltered in muscle.

To examine in vivo insulin sensitivity in 7-d diabetic rats, we performed euglycemic clamp studies in conscious rats. In controls muscle glycogen accounted for $36 \%$ of glucose uptake and glycolysis for $53 \%$ during an insulin clamp study (Fig. $5 \mathrm{D}$ ). Marked impairment in insulin-mediated glucose uptake was demonstrated in 7-d diabetic rats (Fig. $5 \mathrm{~A}$ ) and both glycolysis (Fig. $5 B$ ) and glycogen synthesis (Fig. $5 C$ ) were similarly reduced. Although we have measured glycolysis in the whole 
body, this reflects primarily skeletal muscle as indicated by the fact that measurements of tritrated water specific activity at the end of insulin clamp studies showed highest specific activity in skeletal muscle. In fact, specific activities in all other tissues measured were lower than or similar to plasma (56).

The percent contribution to overall glucose disposal of glycogen synthesis and glycolysis was similar in diabetic and control rats (Fig. $5 \mathrm{D}$ ). These results suggest that the cellular defect responsible for impaired glucose uptake in diabetic rats resides at an early step, i.e., glucose transport or phosphorylation. Alternatively, these results are compatible with severe and similar impairments of both glycolytic and glycogenic pathways. This would necessarily result in an increase in the common substrate for these pathways, G-6-P. However, the concentration of G-6-P is decreased in muscle from diabetic rats (Fig. 6), suggesting impairment in a step proximal to the formation of G-6-P, i.e., glucose transport or phosphorylation. A defect in glucose transport is more likely because phosphorylation has not been shown to be rate limiting for glucose metabolism in muscle (76).

Later, at $14 \mathrm{~d}$ of diabetes GLUT1 and GLUT4 expression are decreased, in agreement with decreased glucose transporter protein $(72,73)$ and mRNA $(16,73)$ levels shown by other investigators. The time at which this decrease occurs probably reflects the severity of the diabetes which may differ depending on the length of hyperglycemia, the degree of volume depletion, the dose and mode of administration of streptozocin, and the size of the rats. The salient point is that at a time when the diabetic rats show markedly diminished insulin-mediated glucose uptake into muscle in vivo (Fig. $5 A$ ), GLUT1 and GLUT4 levels in muscle are normal (Fig. 2 and Table I). Furthermore, a decrease in GLUT4 protein levels in adipose cells preceeds any change in muscle.

Thus, insulin-resistant glucose uptake associated with diabetes may involve a series of steps which ultimately includes reduced glucose transporter expression. This may be part of the generalized catabolic state or a specific effect of "glucose toxicity" or hypoinsulinemia. Importantly, marked insulin-resistant glucose uptake can occur in muscle in the diabetic state without alteration in the levels of GLUT4, the major transporter in muscle fibers, or GLUT1. This suggests defects in the function of glucose transporters which could involve impaired translocation to the plasma membrane, impaired fusion with the plasma membrane, and/or reduced intrinsic activity. We recently demonstrated a "toxic" effect of hyperglycemia on glucose transporter intrinsic activity in adipose cells of diabetic rats (77). Future studies will need to address these potential mechanisms in skeletal muscle.

\section{Acknowledgments}

We thank Drs. D. James, B. Thorens, M. Mueckler, G. Lederkremer, E. Hoffman, and L. Kunkel for providing critical antibodies/antisera and cDNA probes. We are grateful to A. Rosen, D. Banduch, and M. Chafel for expert technical assistance; Dr. A. M. Garcia for microinjection of Xenopus oocytes and assistance in preparing anti-GLUT4 antisera; and Dr. M. Tal and Dr. G. Lederkremer for advice with immunohistochemistry.

This work was supported by Juvenile Diabetes Foundation grants \#189833 (to BBK), \#188016 (to LR), National Institute of Aging Physician Scientist Award \#AG-00294 (to BBK), and National Institutes of Health (NIH) grants \#GM40916 and \#HE41484 (to HFL). MJC was supported by a fellowship from the NIH (\#DK-08101).

\section{References}

1. Mueckler, M., C. Caruso, S. A. Baldwin, M. Panico, I. Blench, H. R. Morris, J. W. Allard, G. E. Lienhard, and H. F. Lodish. 1985. Sequence and structure of a human glucose transporter. Science (Wash. DC). 229:941-945.

2. Birnbaum, M. J., H. C. Haspel, and O. M. Rosen. 1986. Cloning and characterization of cDNA encoding the rat brain glucose-transporter protein. Proc. Natl. Acad. Sci. USA. 83:5784-5788.

3. Fukumoto, H., S. Seino, H. Imura, Y. Seino, R. L. Eddy, Y. Fukushima, M. G. Byers, T. B. Shows, and G. I. Bell. 1988. Sequence, tissue distribution and chromosomal localization of mRNA encoding a human glucose transporter-like protein. Proc. Natl. Acad. Sci. USA. 85:5434-5438.

4. Thorens, B., H. K. Sarkar, H. R. Kaback, and H. F. Lodish. 1988. Cloning and functional expression in bacteria of a novel glucose transporter present in liver, kidney and $\beta$-pancreatic islet cells. Cell. 55:281-290.

5. Kayano, T., H. Fukumoto, R. L. Eddy, Y. Fan, M. G. Byers, T. B. Shows, and G. I. Bell. 1988. Evidence for a family of human glucose transporter-like proteins. J. Biol. Chem. 263:15245-15248.

6. James, D. E., M. Strube, and M. Mueckler. 1989. Molecular cloning and characterization of an insulin-regulatable glucose transporter. Nature (Lond.). 338:83-87.

7. Charron, M. J., F. C. Brosius III, S. L. Alper, and H. F. Lodish. 1989. A novel glucose transporter protein expressed predominately in insulin-responsive tissues. Proc. Natl. Acad. Sci. USA. 86:2535-2539.

8. Birnbaum, M. J. 1989. Identification of a novel gene encoding an insulinresponsive glucose transporter protein. Cell. 57:305-315.

9. Fukumoto, H., T. Kayano, J. B. Buse, Y. Edwards, P. F. Pilch, and G. I. Bell. 1989. Cloning and characterization of the major insulin-responsive glucose transporter expressed in human skeletal muscle and other insulin-responsive tissues. J. Biol. Chem. 264:7776-7779.

10. Kaestner, K. H., R. J. Christy, J. C. McLenithan, L. T. Braiterman, P. Cornelius, P. H. Pekala, and M. D. Lane. 1989. Sequence, tissue distribution, and differential expression of mRNA for a putative insulin-responsive glucose transporter in mouse 3T3-L1 adipocytes. Proc. Natl. Acad. Sci. USA. 86:3150-3154.

11. Bell, G. I., T. Kayano, J. B. Buse, C. F. Burant, J. Takeda, D. Lin, H. Fukumoto, and S. Seino. 1990. Molecular biology of mammalian glucose transporters. Diabetes Care. 13:198-208.

12. Oka, Y., T. Asano, Y. Shibaski, M. Kasuga, Y. Kanazawa, and F. Takaku. 1988. Studies with antipeptide antibody suggest the presence of at least two types of glucose transporter in rat brain and adipocyte. J. Biol. Chem. 263:1343213439.

13. Zorzano, A., W. Wilkinson, N. Kotliar, G. Thoidis, B. E. Wadzinkski, A. E. Ruoho, and P. F. Pilch. 1989. Insulin-regulated glucose uptake in rat adipocytes is mediated by two transporter isoforms present in at least two vesicle populations. J. Biol. Chem. 264:12358-12363.

14. Kahn, B. B., and J. S. Flier. 1990. Regulation of glucose-transporter gene expression in vitro and in vivo. Diabetes Care. 13:548-564.

15. Kahn, B. B., S. W. Cushman, and J. S. Flier. 1989. Regulation of glucose transporter-specific mRNA levels in rat adipose cells with fasting and refeeding: implications for in vivo control of glucose transporter number. J. Clin. Invest. 83:199-204.

16. Garvey, T. W., T. P. Huecksteadt, and M. J. Birnbaum. 1989. Pretranslational suppression of an insulin-responsive glucose transporter in rats with diabetes mellitus. Science (Wash. DC). 245:60-63.

17. Kahn, B. B., M. J. Charron, H. F. Lodish, S. W. Cushman, and J. S. Flier. 1989. Differential regulation of two glucose transporters in adipose cells from diabetic and insulin treated diabetic rats. J. Clin. Invest. 84:404-411.

18. Sivitz, W. I., S. L. DeSautel, T. Kayano, G. I. Bell, and J. E. Pessin. 1989. Regulation of glucose transporter messenger RNA in insulin-deficient states. $\mathrm{Na}$ ture (Lond.). 340:72-74.

19. Berger, J., C. Biswas, P. Vicario, H. V. Strout, R. Saperstein, and P. F. Pilch. 1989. Decreased expression of the insulin-responsive glucose transporter in diabetes and fasting. Nature (Lond.). 340:70-72.

20. Simpson, I. A., and S. W. Cushman. 1986. Hormonal regulation of mammalian glucose transport. Annu. Rev. Biochem. 55:1059-1089.

21. Charron, M. J., and B. B. Kahn. 1990. Divergent molecular mechanisms for insulin resistant glucose transport in muscle and adipose cells in vivo. J. Biol. Chem. 265:7994-8000.

22. Le Marchand-Brustel, Y., and P. Freychet. 1979. Effect of fasting and streptozotocin diabetes on insulin binding and action in the isolated mouse soleus muscle. J. Clin. Invest. 64:1505-1515.

23. Ruderman, N. B., M. N. Goodman, M. Berger, and S. Hagg. 1977. Effect of starvation on muscle glucose metabolism: studies with the isolated perfused rat hindquarter. Fed. Proc. 36:171-176.

24. Goodman, M. N., M. Berger, and N. B. Ruderman. 1974. Glucose metabolism in rat skeletal muscle at rest: effect of starvation, diabetes, ketone bodies and free fatty acids. Diabetes. 23:881-888.

25. DeFronzo, R. A., E. Jacto, E. Jequier, E. Maeder, J. Wahren, and J. P. Felber. 1981. The effect of insulin on the disposal of intravenous glucose. Diabetes. 30:1000-1007. 
26. Yki-Jarvinen, H., A. Young, C. Lamkin, and J. E. Foley. 1987. Kinetics of glucose disposal in whole body and across skeletal muscle in man. J. Clin. Invest. 79:1713-1719.

27. Olefsky, J. M., O. G. Kolterman, and J. A. Scarlett. 1982. Insulin action and resistance in obesity and noninsulin-dependent type II diabetes mellitus. $\mathbf{A m}$. J. Physiol. 243(Endocrinol. Metab. 6):E15-E30.

28. Yki-Jarvinen, H., and V. A. Koivisto. 1984. Insulin sensitivity in newly diagnosed type I diabetics after ketoacidosis and after three months of insulin therapy. J. Clin. Endocrinol. Metab. 287:659-666.

29. DeFronzo, R. A., R. Hendler, and D. Simonson. 1982. Insulin resistance is a prominent feature of insulin dependent diabetes. Diabetes. 31:795-801.

30. Dohm, G. L., E. B. Tapscott, W. J. Pories, D. J. Dabbs, E. G. Flickinger, D. Meelheim, T. Fushiki, S. M. Atkinson, C. W. Elton, and J. F. Caro. 1988. An in vitro human muscle preparation suitable for metabolic studies. Decreased insulin stimulation of glucose transport in muscle from morbidly obese and diabetic subjects. J. Clin. Invest. 82:486-494.

31. Rossetti, L., D. Smith, G. I. Shulman, D. Papachristou, R. A. DeFronzo. 1987. Correction of hyperglycemia with phlorizin normalizes tissue sensitivity to insulin in diabetic rats. J. Clin. Invest. 79:1510-1515.

32. Maegawa, H., M. Kobayashi, S. Ohgaku, M. Iwasaki, N. Watanabe,and Y. Shigeta. 1983. Insulin binding and glucose uptake in isolated soleus muscles in spontaneously non-obese diabetic mice. Biomed. Res. 4:533-536.

33. Chaisson, J.-L., L. Germain, A. Srivastava, and P. Dupuis. 1984. Hormonal regulation of glucose transport in contracting skeletal muscles from normal and diabetic rats. Metabolism. 33:617-621.

34. Wallberg-Henriksson, H., N. Zetan, and J. Henriksson. 1987. Reversability of decreased insulin-stimulated glucose transport capacity in diabetic muscle with in vitro incubation. J. Biol. Chem. 262:7665-7671.

35. Bostrom, M., Z. Nie, G. Goertz, J. Henriksson, and H. Wallberg-Henriksson. 1989. Indirect effect of catecholamines on development of insulin resistance in skeletal muscle from diabetic rats. Diabetes. 38:906-910.

36. Barnard, R. J., J. F. Youngren, D. S. Kartel, and D. A. Martin. 1990 Effects of streptozotocin-induced diabetes on glucose transport in skeletal muscle. Endocrinology. 126:1921-1926.

37. Hansen, I. L., P. E. Cryer, and R. A. Rizza. 1985. Comparison of insulinmediated and glucose-mediated glucose disposal in patients with insulin-dependent diabetes mellitus and in nondiabetic subjects. Diabetes. 34:751-755.

38. Bogardus, C., L. Lillioja, K. Stone, and D. Mott. 1984. Correlation between muscle glycogen synthase activity and in vivo insulin action in man. $J$. Clin. Invest. 73:1186-1190.

39. Mandarino, L., Z. Mader, O. G. Kolterman, J. M. Bell, and J. M. Olefsky. 1986. Adipocyte glycogen synthase and pyruvate dehydrogenase in obese and type II diabetic subjects. Am. J. Physiol. 251:E489-E496.

40. Foley, J. E., and T. P. Huecksteadt. 1984. Glucose-6-phosphate effects on deoxyglucose, glucose and methylglucose transport in rat adipocytes: evidence for intracellular regulation of sugar transport by glucose metabolites. Biochim. Biophys. Acta. 805:313-316.

41. Froehner, S. C., A. Davies, S. A. Baldwin, and G. E. Lienhard. 1988. The blood-nerve barrier is rich in glucose transporter. $J$. Neurocytol. 17:173-178.

42. Vilaro, S. M. Palacin, P. F. Pilch, X. Testar, and A. Zorzano. 1989. Expression of an insulin-regulatable glucose carrier in muscle and fat endothelial cells. Nature (Lond.). 342:789-800.

43. Slot, J. W., R. Moxley, H. J. Geuze, and D. E. James. 1990. No evidence for expression of the insulin-regulatable glucose transporter in endothelial cells. Nature (Lond.). 346:369-371.

44. Kahn, B. B., and S. W. Cushman. 1987. Mechanism for markedly hyperresponsive insulin-stimulated glucose transport activity in adipose cells from insulin-treated streptozotocin diabetic rats: evidence for increased glucose transporter intrinsic activity. J. Biol. Chem. 262:5118-5124.

45. Green, N., H. Alexander, A. Olson, S. Alexander, T. M. Shinnick, J. G. Sutcliffe, and R. A. Lerner. 1982. Immunogenic structure of the influenza virus hemagglutin. Cell. 28:477-487.

46. Garcia, A. M., and H. F. Lodish. 1989. Lysine 539 of human band 3 is not essential for ion transport or inhibition by stilbene disulfonates. J. Biol. Chem 264:19607-19613.

47. Colman, A. 1984. Transcription and Translation: A Practical Approach. B. D. Hames and S. J. Higgins, editors. IRL Press, Oxford. 271-302.

48. Bischoff, J., and H. H. Lodish. 1987. Two asialoglycoprotein receptor polypeptides in human hepatoma cells. J. Biol. Chem. 262:11825-11832.

49. Amara, J. F., G. Lederkremer, and H. F. Lodish. 1989. Intracellular degradation of unassembled asialoglycoprotein receptor subunits: a pre-golgi, nonlysosomal endoproteolytic cleavage. J. Cell. Biol. 109:3315-3324.

50. Hoffman, E. P., A. H. Beggs, M. Koenig, L. M. Kunkel, and C. Angelini. 1989. Crossreactivity in Duchenne muscle. Lancet. ii:1211-1212.

51. Pedersen, O., J. F. Bak, P. H. Andersen, S. Lund, D. E. Moller, J. S. Flier, and B. B. Kahn. 1990. Evidence against altered expression of GLUT1 or GLUT4 in skeletal muscle of patients with obesity or NIDDM. Diabetes. 39:865-870.

52. Klip, A., T. Ramlal, D. A. Young, and J. O. Holloszy. 1987. Insulin-induced translocation of glucose transporters in rat hind-limb muscles. FEBS (Fed. Eur. Biochem. Soc.) Lett. 224:224-230.

53. Simpson, I. A., and O. Sonne. 1982. A simple, rapid and sensitive method for measuring protein concentration in subcellular membrane fractions prepared by sucrose density centrifugation. Anal. Biochem. 119:424-427.

54. Chirgwin, J. M., A. W. Przbyla, R. J. MacDonald, and W. J. Rutter. 1979. Isolation of biologically active ribonucleic acid from sources enriched in ribonuclease. Biochemistry. 18:5294-5299.

55. Labarca, C., and K. Paigen. 1980. A simple rapid and sensitive DNA assay procedure. Ann. Biochem. Exp. Med. (Calcutta). 102:344-351.

56. Rossetti, L., and A. Giaccari. 1990. Relative contribution of glycogen synthesis and glycolysis to insulin-mediated glucose uptake. J. Clin. Invest. 85:1785-1792.

57. Rossetti, L. 1989. Normalization of insulin sensitivity with lithium in diabetic rats. Diabetes. 38:648-652.

58. Rossetti, L., and M. R. Laughlin. 1989. Correction of chronic hyperglycemia with vanadate, but not phlorizin, normalizes in vivo glycogen repletion and in vitro glycogen synthase activity in diabetic skeletal muscle. J. Clin. Invest. 84:892-899.

59. Shulman, G. I., L. Rossetti, D. Rothman, J. Blair, and D. Smith. 1987 Quantitative analysis of glycogen repletion of nuclear magnetic resonance spectroscopy in the conscious rat. J. Clin. Invest. 80:387-393.

60. Rossetti, L. D. L. Rothman, R A. DeFronzo, and G. I Shulman 1989 Effect of dietary protein on in vivo insulin action and liver glycogen repletion. Am. J. Physiol. 257:E212-E219.

61. Young, A. A., C. Bogardus, D. Wolfe-Lopez, and D. M. Mott. 1988 Muscle glycogen synthesis disposition of infused glucose in humans with reduced rates of insulin-mediated carbohydrate storage. Diabetes. 37:303-308.

62. Karlander, S., A. Roovete, M. Vranic, and S. Efendic. 1986. Glucose and fructose-6-phosphate cycle in humans. Am. J. Physiol. 251:E530-E536.

63. Hostler, K. Y., and B. R. Landau. 1967. Estimation of the pentose cycle contribution to glucose metabolism in tissue in vivo. Biochemistry. 6:2961-2964

64. Spense, J. T., and A. P. Koudelka. 1985. Pathway of glycogen synthesis from glucose in hepatocytes maintained in primary culture. J. Biol. Chem. 260:1521-1526.

65. Michal, G. 1985. Methods of Enzymatic Analysis. Vol VI. N. U. Bergmeyer, editor, VCH Verlagsgesellschaft mbH, Weinheim, FRG. 191-198.

66. Kubo, K., and J. E. Foley. 1986. Rate-limiting steps for insulin-mediated glucose uptake into perfused rat hindlimb. Am. J. Physiol. 250:E100-E102.

67. Gottesman, I., L. Mandarino, C. Verdonk, R. Rizza, and J. Gerich. 1982. Insulin increases the maximum velocity for glucose uptake without altering the Michaelis constant in man. J. Clin. Invest. 70:1310-1314.

68. Katz, A., B. L. Nyomba, and C. Bogardus. 1988. No accumulation of glucose in human skeletal muscle duting euglycemic hyper-insulinemia. Am. J. Physiol. 255:E942-E945.

69. Ferrannini, E., J. D. Smith, C. Cobelli, G. Toffolo, A. Pilo, and R. A. DeFronzo. 1985. Effect of insulin on the distribution and disposition of glucose in man. J. Clin. Invest. 76:357-364.

70. Ziel, F. H., N. Venkatesan, and M. B. Davidson. 1988. Glucose transport is rate limiting for skeletal muscle glucose metabolism in normal and STZ-induced diabetic rats. Diabetes. 37:885-890.

71. Yki-Jarvinen, H., K. Sahlin, J. M. Ren, and V. A. Koivisto. 1990. Localization of rate-limiting defect for glucose disposal in skeletal muscle of insulin-resistant type I diabetic patients. Diabetes. 39:157-167.

72. Ramlal, T., S. Rastogi, M. Vranic, and A. Klip. 1989. Decrease in glucose transporter number in skeletal muscle of mildly diabetic (streptozotocin-treated) rats. Endocrinology. 125:890-897.

73. Strout, H. V., P. P. Vicario, C. Biswas, R. Saperstein, E. J. Brady, P. F. Pilch, and J. Berger. 1990. Vanadate treatment of streptozotocin diabetic rats restores expression of the insulin-responsive glucose transporter in skeletal muscle. Endocrinology. 126:2728-2732.

74. Maegawa, H., M. Kobayashi, N. Watanabe, O. Ishibashi, Y. Takata, E. Kitamura, and Y. Shigeta. 1986. Effect of duration of diabetic state on insulin action in isolated rat soleus muscles. Metabolism. 35:499-504.

75. Thorens, B., J. S. Flier, H. F. Lodish, and B. B. Kahn. 1990. Expression of two glucose transporters in rat liver is differentially regulated by fasting and refeeding and by diabetes and insulin treatment. Diabetes. 39:712-719.

76. Grossbard, L and R. T. Schimke 1966. Multiple hexokinases in rat tissues. J. Biol. Chem. 241:3546-3560.

77. Kahn, B. B., G. I. Shulman, R. A. DeFronzo, S. W. Cushman, and L. Rossetti. 1991. Normalization of blood glucose in diabetic rats with phlorizin treatment reverses insulin-resistant glucose transport in adipose cells without restoring glucose transporter gene expression. J. Clin. Invest. 87:561-570. 